\title{
Short Communication: Ethnobotanical study of wild and cultivated vegetables in the Eastern Cape Province, South Africa
}

\author{
ALFRED MAROYI ${ }^{\vee}$ \\ Department of Biodiversity, University of Limpopo. Private Bag X1106, Sovenga 0727, South Africa; Tel./fax.: +27-719600326, \\ "email: alfred.maroyi@gmail.com
}

Manuscript received: 12 July 2020. Revision accepted: 6 August 2020.

\begin{abstract}
Maroyi A. 2020. Short Communication: Ethnobotanical study of wild and cultivated vegetables in the Eastern Cape Province, South Africa. Biodiversitas 21: 3982-3988. Vegetables are an important component of agricultural biodiversity required for providing a wide range of ecosystem goods and services. The current study was undertaken in the Eastern Cape Province, South Africa to document wild and cultivated vegetables. Research data were collected by means of interviews and field surveys carried out in different seasons with one hundred and thirty-eight randomly selected participants. During the interviews, we documented information on names of edible vegetables, uses, plant parts consumed, and their preparation. A total of 32 species belonging to 26 genera and 15 families were recorded in the study area. The plant families with highest number of vegetable species were Amaranthaceae, Asteraceae, and Solanaceae with at least four species each. The main uses of vegetables identified in the study area were leafy vegetables $(59.4 \%)$, edible fruits and tubers (21.9\% each), culinary herbs or spices $(12.5 \%)$, edible seeds $(9.4 \%)$ and edible stems $(6.3 \%)$. The species which were categorized as important with relative frequency of citation (RFC) values $>0.3$ were Brassica oleracea, Solanum tuberosum, Cucurbita moschata, Spinacia oleracea, and Cucurbita maxima. Both vegetable species collected from the wild and conventional vegetables cultivated in home gardens are important to livelihoods needs of the local people.
\end{abstract}

Keywords: Agricultural biodiversity, food security, livelihoods, Eastern Cape Province, South Africa, vegetables

\section{INTRODUCTION}

Plants are essential for human nutrition and as sources of energy. Bennett (2010) argued that humans obtain $85 \%$ of their calories from 20 plant species while more than $50 \%$ of their calories are derived from three plant species only, namely Oryza sativa L. (rice), Triticum aestivum L. (wheat) and Zea mays L. (maize). But in sub-Saharan Africa and other marginal environments of developing countries, there are several edible plant species often collected from the wild or grown in home gardens. Research by Maundu et al. (2009) revealed that there are about 1000 plant species in sub-Saharan Africa that are used as vegetables, with $80 \%$ of these being leafy vegetables and the rest are cultivated or collected from the wild for their edible fruits, seeds, roots and tubers, stems and flowers. A growing body of literature suggests small to medium-sized farming communities in remote and marginal areas have significant number of agricultural biodiversity required for food security and the wider provisioning of crucial ecosystem goods and services (Kumar and Nair 2004; Clarke et al. 2014; FAO 2019; Thorn et al. 2020). According to FAO (2001), food security, at the individual, household, national, regional and global levels is achieved when all people, at all times, have physical, social and economic access to sufficient, safe and nutritious food to meet their dietary needs and food preferences for a healthy and active life. Access to sufficient, safe, and nutritious food means that households must have adequate resources either to produce food in different farming systems or to obtain the food in exchange for cash or other commodities.

The significance of ecosystem goods and services provided by vegetables to community livelihoods is appreciated throughout the world (Afari-Sefa et al. 2011; Keatinge et al. 2011; Ebert 2014; Ojiewo et al. 2015; Ochieng et al. 2017). Towns and Shackleton (2018) argued that these different species of vegetables contribute to the dietary diversity, and are an important part of alimentary traditions, cultural identity of local communities in subSaharan Africa and make significant contribution to the development of agricultural biodiversity, but have suffered as neglected and underutilized species. These vegetable species have potential to be developed into new crops through domestication and their documentation is necessary for the identification of food sources from different environments and regions in order to serve as gene pools for genetic improvement of crops to achieve higher productivity, disease resistance and compatibility with global climate change (Turner et al. 2011; Ju et al. 2013; Abbet et al. 2014; Das et al. 2016; Aryal et al. 2018; Shin et al. 2018). There is now a general consensus that vegetables and other wild edible plants play an important role to the food basket in much of the developing world (Rubatzky and Yamaguchi 1997; Sundriyal et al. 2004; Ali-Shtayeh et al. 2008; Misra et al. 2008; MenendezBaceta et al. 2012; Thakur et al. 2017; Bhatia et al. 2018; Chauhan et al. 2018) and leafy wild vegetables and fruits 
are an important source of food during drought periods when the staple crops fail (Shin et al. 2018; Ojelel et al. 2019).

There is growing interest on vegetables since daily diet of fruits and vegetables is strongly associated with improved gastrointestinal health, reduced risk of heart diseases, stroke, chronic diseases such as diabetes, eye problems and various forms of cancer (Heinrich et al. 2005; Leonti et al. 2006; Dias 2012; Romojaro et al. 2013; Rush et al. 2018; Sansanelli et al. 2018). Similarly, Schreinemachers et al. (2018) argued that vegetables are the most affordable food source of vitamins and minerals needed by humans for good health. It is, therefore, within this context that this study was undertaken focusing on wild and cultivated vegetables in the Eastern Cape Province, South Africa. The term vegetable is defined as an annual or perennial horticultural crop with its parts such as roots, stalks, flowers, fruits, and leaves that can be consumed wholly or partially in raw form or after cooking (Welbaum 2015; Ülger et al. 2018). This knowledge on vegetables is important for preservation of ethnobotanical knowledge as part of the cultural knowledge and practice of local communities. Therefore, the aim of this study was to assess diversity, use categories, and local knowledge of both wild and cultivated vegetables in the Eastern Cape Province in South Africa.

\section{MATERIALS AND METHODS}

\section{Study area}

The study was conducted in three local municipalities in the Eastern Cape Province in South Africa, namely
Elundi, Mbhashe, and Raymond Mhlaba Local Municipalities (Figure 1). The area is characterized by a subtropical climate with cold and wet winters, and warm and wet summers. Annual temperatures range from $4{ }^{\circ} \mathrm{C}$ in winter to a maximum of $40{ }^{\circ} \mathrm{C}$ in the summer (Jari and Fraser 2012; Hosu et al. 2016; Ndhlevu et al. 2017). The study area experiences an annual rainfall ranging from 550 $\mathrm{mm}$ to $1000 \mathrm{~mm}$ (Manyevere et al. 2014; Hosu et al. 2016; Ndhlevu et al. 2017). The local residents also rely on natural plant resources and the surrounding environment for a diversity of livelihood needs (Alexander et al. 2015) in addition to subsistence agriculture and migrant labor. The general livelihood system in the study area can be described as a mixed farming system, with residents engaging in both crop and livestock farming. Crop production is mainly through irrigation and rain-fed farming and some of the cultivated crops include maize (Zea mays), sorghum (Sorghum bicolor (L.) Moench), potatoes (Solanum tuberosum L.), cabbage (Brassica oleracea L.), spinach (Spinacia oleracea L.), beetroot (Beta vulgaris L.) and carrots (Daucus carota L.) (Ndhleve et al. 2013). The most common livestock species in the study area include cattle, chickens, donkeys, goats, horses, pigs, and sheep (Mapekula et al. 2009; Fayemi and Muchenje 2014; Mthi et al. 2017). Other sources of livelihoods include temporary employment, art and craft activities, social grants, and remittances from family members working in towns. The grassland biome and succulent thicket are by far the most dominant biomes in the study area (Mucina and Rutherford 2006).

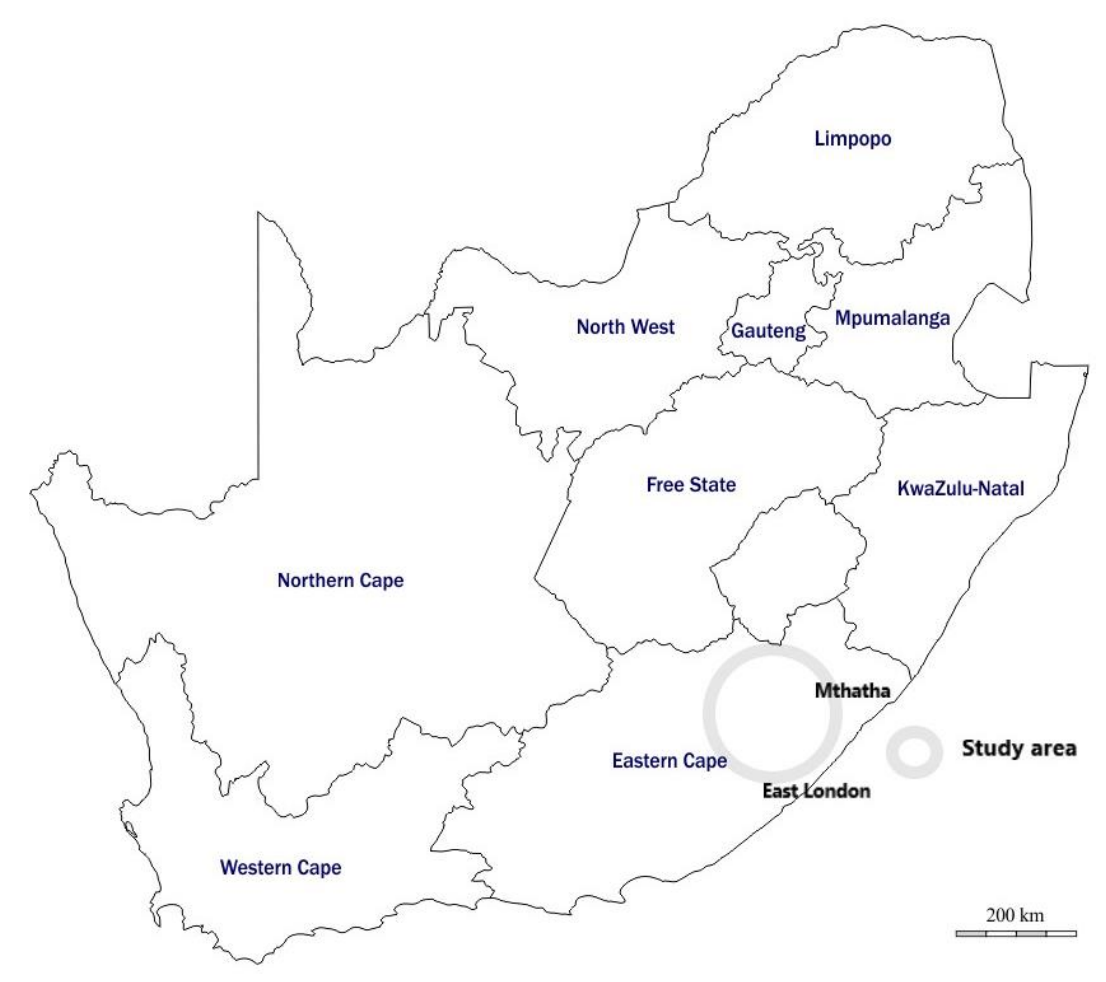

Figure 1: The geographical position of the study sites in relation to other provinces in South Africa 


\section{Data collection}

Data on the diversity of wild and cultivated vegetables in the Eastern Cape Province were collected by means of interviews and field surveys carried out in different seasons, that is, winter and summer. One hundred and thirty eight (Table 1) randomly selected participants took part in this study conducted between March 2012 to March 2017. This study utilized the participatory rural appraisal (PRA) methods (Chambers 1994), focusing on in-depth discussions using open-ended questionnaires and participant observation with local communities in data gathering. Interview discussions took place in the local language, isiXhosa, and were translated into English with the help of an interpreter. During the interviews, we documented information on names of edible vegetables, uses, plant parts consumed, and their preparation. Plant species were identified in the field and the taxon names conform to those of Germishuizen and Meyer (2003). The majority of these participants $(65.9 \%)$ were females and their age range was from 19 to 81 years (Table 1). More than $80 \%$ of the participants live below the national poverty line and $62.3 \%$ of the households had total income of less than R1000.00 (US\$87.00) per month. Close to threequarters of the participants $(73.9 \%)$ were unemployed, with $63.0 \%$ surviving on social grants (Table 1 ).

\section{Data analysis}

This research employed combination of qualitative and quantitative methods. The data collected were entered in Microsoft Excel 2007 file and this data was used to determine frequencies and other descriptive statistical patterns. The local importance of vegetable plant species was assessed using the relative frequency of citation (RFC). This index, is a result of the frequency of citation (FC), the number of informants mentioning the use of the species, divided by the total number of informants $(\mathrm{N})$ (Tardío and Pardo-de-Santayana 2008).

$$
\mathrm{RFC}=\mathrm{FC} / \mathrm{N}
$$

The informant consensus factor (ICF) of vegetables was also assessed aimed at evaluating the level of homogeneity of information provided by the participants (Trotter and Logan 1986). The index was calculated as the number of use citations in each category minus the number of species used divided by the number of use citations in each category minus one. The formula of ICF index is:

$$
\mathrm{ICF}=\frac{N u r-N t}{N u r-1}
$$

Where,

Nur $=$ number of use reports from informants for a particular plant-use category,

$\mathrm{Nt}=$ number of species that are used for that plant use category based on information provided by participants.

The box plots featuring medians, first and third quartiles, and a range of plant use categories were computed using Palaeontological Statistics (Hammer et al. 2001) version 3.06.

\section{RESULTS AND DISCUSSION}

\section{Diversity of edible vegetables}

A total of 32 plant species belonging to 26 genera and 15 families were recorded in the Eastern Cape Province (Table 2). More than three-quarters of the documented vegetables $(81.3 \%)$ are from nine families, namely Asteraceae, Solanaceae, Amaranthaceae, Amaryllidaceae, Apiaceae, Araceae, Brassicaceae, Cucurbitaceae, and Fabaceae (Table 3). The other plant families were represented by one species each. Similar research by Achigan-Dako et al. (2011) focusing on diversity of vegetables in Benin revealed dominance of species belonging to families Amaranthaceae, Asteraceae, Cucurbitaceae, Fabaceae and Solanaceae. Moreover, the major families identified in this study are among the largest plant families in South Africa characterized by more than 50 species each (Germishuizen and Meyer 2003). Some of the vegetable species belonging to families Amaranthaceae, Amaryllidaceae, Apiaceae, Araceae, Asteraceae, Brassicaceae, Cucurbitaceae, Fabaceae, and Solanaceae are included in the book "Plant Resources of Tropical Africa 2: Vegetables", a monographic guide to the most commonly used vegetable species in tropical Africa, including their botany, distribution, main uses and phytochemical properties (Grubben and Denton 2004).

More than three quarters $(81.3 \%)$ of recorded vegetables are exotic to South Africa with the exception of Catha edulis (Vahl) Endl., Centella coriacea Nannf., Mentha longifolia (L.) Huds., Portulacaria afra Jacq., Solanum retroflexum Dun. and Zantedeschia aethiopica (L.) Spreng. Turreira-García et al. (2017) argued that presence of $55.0 \%$ exotic leafy vegetable species in Thailand serves as confirmation of international crop exchange in that country. Similarly, Maundu et al. (2009) argued that exotic species reported in this study such as Cucurbita maxima Duchesne and C. moschata Duchesne ex Poir. are originally from South America and now widely cultivated in tropical Africa for their edible fruits and leaves. In previous research focusing on edible vegetables in the KwaZulu-Natal province in South Africa, Ntuli et al. (2012) revealed that $47.0 \%$ of the documented species were exotic to South Africa. The authors argued that indigenous knowledge systems of local communities in KwaZuluNatal province are dynamic and usually incorporate exotic species as new food sources.

Table 1. Socio-economic characteristics of the study sample, $n=$ 138

\begin{tabular}{ll}
\hline Socio-economic variable & Value \\
\hline Gender: Female & $65.9 \%$ \\
Male & $34.1 \%$ \\
Age & $19-81$ years (median 57 years) \\
People living in poverty & $80.4 \%$ \\
Household income & $62.3 \%$ \\
(<R1000.00 (US\$87.00) & \\
Unemployed & $73.9 \%$ \\
Dependent on social grants & $63.0 \%$ \\
Household size & $1-12$ people (average 4.5) \\
\hline
\end{tabular}


Table 2. List of vegetable species recorded in the Eastern Cape Province, arranged in descending order of importance

\begin{tabular}{|c|c|c|c|c|c|}
\hline Scientific name & Family & $\begin{array}{l}\begin{array}{l}\text { Xhosa } \\
\text { names }\end{array} \\
\end{array}$ & Habit & Edible part & RFC \\
\hline Brassica oleracea $\mathrm{L}$. & Brassicaceae & Cabbage (E), ikhaphetshu (X) & Herb & Leaves & 0.572 \\
\hline Solanum tuberosum $\mathrm{L}$. & Solanaceae & Amazambane $(X)$, potato $(E)$ & Herb & Tubers & 0.543 \\
\hline $\begin{array}{l}\text { Cucurbita moschata Duchesne ex } \\
\text { Poir. }\end{array}$ & Cucurbitaceae & Butternut (E), ithanga (X) & Climber & $\begin{array}{l}\text { Fruits and young } \\
\text { shoots }\end{array}$ & 0.507 \\
\hline Spinacia oleracea L. & Amaranthaceae & Imifuno $(X)$, spinach $(E)$ & Herb & Leaves & 0.486 \\
\hline Cucurbita maxima Duchesne & Cucurbitaceae & Ithanga $(X)$, pumpkin $(E)$ & Climber & $\begin{array}{l}\text { Fruits, seeds and } \\
\text { young shoots }\end{array}$ & 0.428 \\
\hline Capsicum аппиит $\mathrm{L}$. & Solanaceae & Itshilisi (X), pepper (E) & Shrub & Fruits & 0.283 \\
\hline Daucus carota $\mathrm{L}$. & Apiaceae & Carrots (E), umnqathi (X) & Herb & Tubers & 0.268 \\
\hline Lycopersicon esculentum Mill. & Solanaceae & Tomato (E), tumata $(\mathrm{X})$ & Shrub & Fruits & 0.254 \\
\hline Ipomoea batatas (L.) Lam. & Convolvulaceae & Bhatata $(X)$, sweet potato $(E)$ & Climber & Tubers & 0.152 \\
\hline Phaseolus vulgaris $\mathrm{L}$. & Fabaceae & Bean (E), mbotyi (X) & Herb & Fruits and se & 0.130 \\
\hline Lactuca sativa $\mathrm{L}$. & Asteraceae & Ilethasi (X), lettuce (E) & Herb & & 0.094 \\
\hline um $\mathrm{L}$. & Fabaceae & Erityisi (X), pea (E) & Herb & ad seeds & 0.087 \\
\hline apa $\mathrm{L}$. & Bras & Turn & Herb & $\mathrm{Le}$ & 0.079 \\
\hline hus hybridus L. & Amaranthaceae & Nomdlomboyi (X), Pigweed (E) & Herb & & 0.072 \\
\hline Allium cepa $\mathrm{L}$. & Amaryllidaceae & Itswele $(\mathrm{X})$, onion $(\mathrm{E})$ & Herb & $\mathrm{Tu}$ & 0.065 \\
\hline Bidens pilosa $\mathrm{L}$. & Asteraceae & Umhlabangulo (X), Blackjack (E) & Herb & Lea & 0.058 \\
\hline Sonchus oleraceus (L.) L. & Asteraceae & Ihlaba $(\mathrm{X})$, wild sowthistle & Herb & Lea & 0.051 \\
\hline Centella coriacea Nannf. & Apiaceae & Unongotyozana $(\mathrm{X})$ & Herb & Leaves & 0.051 \\
\hline Allium sativum $\mathrm{L}$. & Amaryllidaceae & Garlic (E) & Herb & Tubers & 0.051 \\
\hline Catha edulis (Vahl) Endl. & Celastraceae & Iqwaka $(X)$, khat $(\mathrm{E})$ & Tree & Leaves & 0.043 \\
\hline Chenopodium album $\mathrm{L}$. & Amaranthaceae & Goosefoot (E), imbikicane (X) & Herb & Leaves & 0.043 \\
\hline Mentha longifolia (L.) Huds. & Lamiaceae & Mint (E) & Herb & Leaves & 0.036 \\
\hline Sonchus asper (L.) Hill & Asteraceae & Irwabe $(X)$, spiny sowthistle $(E)$ & Herb & Leaves & 0.036 \\
\hline Beta vulgaris $\mathrm{L}$. & Amaranthaceae & Beetroot (E), Bhetruthi & Herb & Tubers & 0.029 \\
\hline Portulaca oleracea $\mathrm{L}$. & Portulacaceae & Igwanisha $(X)$, pigweed $(E)$ & Shrub & Leaves a & 0.029 \\
\hline Solanum retroflexum Dun. & Solanaceae & Nightshade (E), umsobo wehlathi & Shrub & Fruits and leaves & 0.029 \\
\hline Colocasia antiquorum Schott & Araceae & Idumbe $(\mathrm{X})$ & Herb & Tubers & 0.021 \\
\hline Portulacaria afra Jacq. & Didiereaceae & Igwanitsha (X), Spekboom (E) & Shrub & Leaves and stems & 0.021 \\
\hline Rumex lanceolatus Thunb. & Polygonaceae & Idolo lenkonyane (X) & Herb & Leaves & 0.014 \\
\hline Solanum nigrum L. & Solanaceae & Nightshade (E), Umsobo (X) & Shrub & Fruits and leaves & 0.014 \\
\hline Taraxacum officinale Weber & Asteraceae & Uqudalele (X) & Herb & & 0.007 \\
\hline Zantedeschia aethiopica (L.) Spreng. & Araceae & Ntebe $(\mathrm{X})$ & Herb & Tubers & 0.007 \\
\hline
\end{tabular}

Table 3. Different plant families with at least two species of edible vegetables in the study area

\begin{tabular}{lcc}
\hline Family & No. of species & $\begin{array}{c}\text { Proportion } \\
(\%)\end{array}$ \\
\hline Asteraceae & 5 & 15.6 \\
Solanaceae & 5 & 15.6 \\
Amaranthaceae & 4 & 12.5 \\
Amaryllidaceae & 2 & 6.3 \\
Apiaceae & 2 & 6.3 \\
Araceae & 2 & 6.3 \\
Brassicaceae & 2 & 6.3 \\
Cucurbitaceae & 2 & 6.3 \\
Fabaceae & 2 & 6.3 \\
\hline
\end{tabular}

\section{Edible parts}

More than half of the plant species recorded as vegetables in the Eastern Cape Province were herbs, followed by shrubs and climbers (Figure 2). Similar results were reported by Ntuli et al. (2012) based on research of edible vegetables in the KwaZulu-Natal province in South Africa who reported dominance of herbs $(65.0 \%)$, followed by semi-woody or herbaceous climbers $(24.0 \%)$, shrubs and trees $(11.0 \%$ in total). Results from ethnobotanical research of edible vegetables conducted in other African countries like Benin, Cameroon, Guinea-Bissau and Kenya revealed the dominance of herbs with overall percentage ranging from $61.5 \%$ to $64.5 \%$ (Orech et al. 2007; Dansi et al. 2008; Ngone et al. 2016; Catarino et al. 2019). Among the main uses of vegetables identified in the study area were leafy vegetables $(59.4 \%)$, edible fruits and tubers (21.9\% each), culinary herbs or spices $(12.5 \%)$, edible seeds $(9.4 \%)$ and edible stems (6.3\%) (Figure 3). The species regarded as important with RFC values $>0.3$ were Brassica oleracea (leafy vegetable), Solanum tuberosum (edible tubers), Cucurbita moschata (edible fruits and leafy vegetable), Spinacia oleracea (leafy vegetable) and Cucurbita maxima (edible fruits, seeds, and leafy vegetable) (Table 2). The species categorized as of little value with RFC values $<0.02$ were Rumex lanceolatus Thunb. (leafy vegetable), Solanum nigrum L. (edible fruits and leafy vegetables), Taraxacum officinale Weber (leafy vegetables), and Zantedeschia aethiopica (edible tubers) (Table 2). The edible stems and leafy vegetables were not popular food sources as supported by low RFC values in comparison to other use categories like edible tubers, fruits 
and seeds, and culinary herbs or spices (Figure 4). In the present study, the ICF values for the documented vegetables ranged from 0.21 to 0.71 (Table 4). The highest agreement between the participants was observed for leafy vegetables while the least agreement was for edible stems (Table 3).

Interviews with participants revealed that species like Rumex lanceolatus, Solanum nigrum, Taraxacum officinale, and Zantedeschia aethiopica were rarely eaten by the local inhabitants, while conventional cultivated vegetables like Brassica oleracea, Solanum tuberosum, Cucurbita moschata, Spinacia oleracea, and Cucurbita maxima were preferred and, thus, scored higher RFC values (Table 2). The exotic vegetable species such as Brassica oleracea, Solanum tuberosum, Cucurbita moschata, Spinacia oleracea, and Cucurbita maxima are well-known food plants cultivated throughout the world (Semenya and Maroyi, 2020). Kahane et al. (2013) and Caballero-Serrano et al. (2016) argued that indigenous and wild species are less attractive to communities as these species are usually seasonal and inaccessible in some cases unlike the majority of conventional vegetable species that are easy to cultivate and manage in home gardens. Previous research on wild vegetables in the Eastern Cape Province by Bhat and Rubuluza (2002) and Bvenura and Afolayan (2014) also found a decline in wild vegetable consumption. Uprety et al. (2012) argued that documentation and conservation of wild edible plants are important as this would ensure that the highest priority genetic diversity is preserved and made available for use in crop improvement programs as a contribution to future worldwide food security. Moreover, documenting such information on utilization of plant species based on perceptions of local communities is an important step in trying to understand and initiate a management protocol that incorporates public perceptions and values associated with utilization of plant resources (Atyosi et al., 2019).

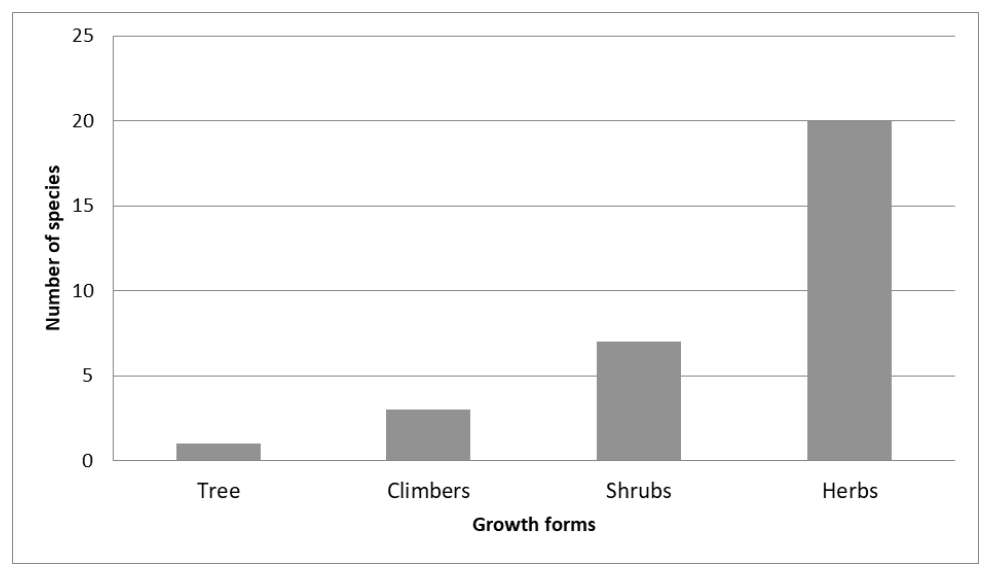

Figure 2. Growth forms of vegetable species recorded in the Eastern Cape Province

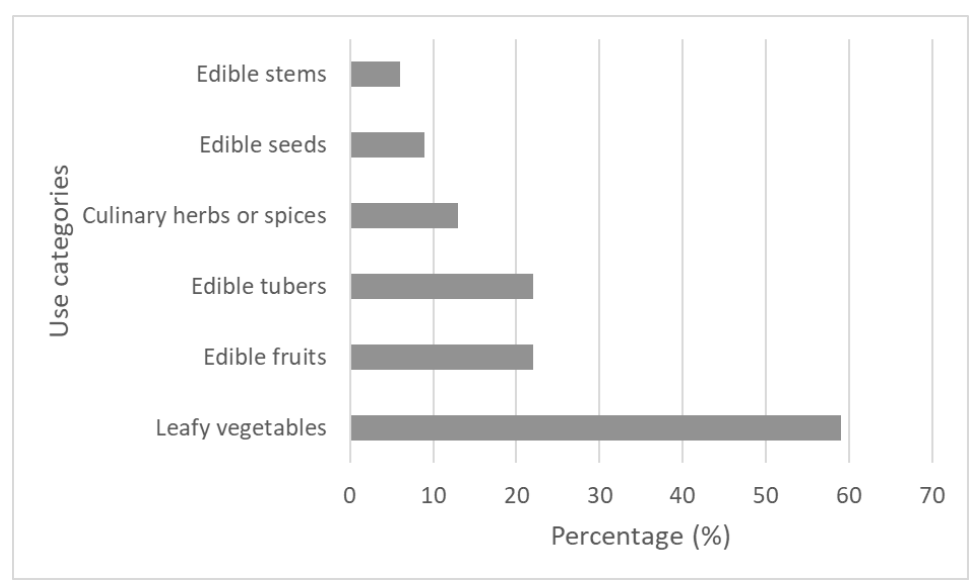

Figure 3. Categorization of vegetables recorded in the Eastern Cape Province 


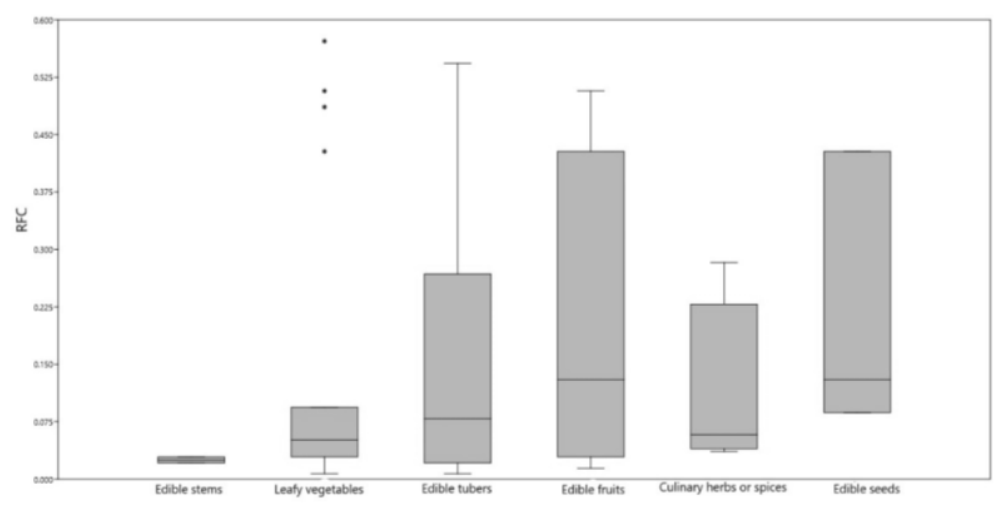

Figure 4. Relationship of relative frequency citation $(\mathrm{RFC})$ and different use values. Box $=$ standard error, whisker $=$ standard deviation, line in box $=$ mean and $\circ=$ outlier

Table 4. Number of species and informant consensus factor (ICF) in each use category

\begin{tabular}{lccc}
\hline \multicolumn{1}{c}{ Use category } & $\begin{array}{c}\text { No. of } \\
\text { species }\end{array}$ & $\begin{array}{c}\text { \% of species } \\
\text { used }\end{array}$ & ICF \\
\hline Leafy vegetables & 19 & 59.4 & 0.71 \\
Edible tubers & 7 & 21.9 & 0.68 \\
Culinary herbs or spices & 4 & 12.5 & 0.57 \\
Edible fruits & 7 & 21.9 & 0.56 \\
Edible seeds & 3 & 9.4 & 0.37 \\
Edible stems & 2 & 6.3 & 0.21 \\
\hline
\end{tabular}

In conclusion, results of this study have added invaluable information on edible vegetable species in the Eastern Cape Province in South Africa. The value of different forms of vegetables as sources of food needs to be appreciated by agriculturalists, government policymakers, and scientists responsible for research, extension activities, and agricultural policy. Irrespective of their social or economic status all participants in this study shared their knowledge and how different vegetable types are used. Therefore, both wild vegetable species and conventional vegetables are relevant to livelihood needs of the local people.

\section{ACKNOWLEDGEMENTS}

The author would like to thank local communities for participating in this study.

\section{REFERENCES}

Abbet C, Mayor R, Roguet D, et al. 2014. Ethnobotanical survey on wild alpine food plants in lower and Central Valais (Switzerland). Ethnopharmacol 151 (1): 624-634.

Achigan-Dako E, N'Danikou S, Assogba-Komlan F, et al. 2011. Diversity, geographical, and consumption patterns of traditional vegetables in sociolinguistic communities in Benin: implications for domestication and utilization. Economic Botany 65: 129-145.

Afari-Sefa V, Tenkouano A, Ojiewo CO, et al. 2011. Vegetable breeding in Africa: constraints, complexity and contributions toward achieving food and nutritional security. Food Security 4: 115-127.
Alexander J, Cocks ML, Shackleton C. 2015. The landscape of childhood: play and place as tools to understanding children's environmental use and perceptions. Human Ecology 43: 467-480.

Ali-Shtayeh MS, Jamous RM, Al-Shafie JH, et al. 2008. Traditional knowledge of wild edible plants used in Palestine (Northern West Bank): a comparative study. Journal of Ethnobiology and Ethnomedicine 4: 13. https://doi.org/10.1186/1746-4269-4-13.

Aryal KP, Poudel S, Chaudhary RP, et al. 2018. Diversity and use of wild and noncultivated edible plants in the Western Himalaya. J Ethnobiol Ethnomed 14: 10.

Atyosi Z, Ramarumo LJ, Maroyi A. 2019. Alien plants in the Eastern Cape Province in South Africa: Perceptions of their contributions to livelihoods of local communities. Sustainability 11 (18): 5043. DOI: 10.3390/su11185043.

Bennett BC. 2010. Plants as food. In: Bennett B (Ed.), Economic botany: Encyclopedia of life support systems (EOLSS). Eolss publishers, Oxford, UK.

Bhat RB, Rubuluza T. 2002. The bio-diversity of traditional vegetables of the Transkei region in the Eastern Cape of South Africa. S Afr J Bot 68 (1): 94-97.

Bhatia H, Sharma YP, Manhas PK, et al. 2018. Traditionally used wild edible plants of district Udhampur, J\&K, India. J Ethnobiol Ethnomed 14 (1): 73.

Bvenura C, Afolayan AJ. 2014. Ethnobotanical survey of wild vegetables in Mbashe and Nkonkobe municipalities, Eastern Cape Province, South Africa. Acta Botanica Gallica Botany Letters 161 (2): 189-199.

Caballero-Serrano V, Onaindia M, Alday JG, et al. 2016. Plant diversity and ecosystem services in Amazonian homegardens of Ecuador. Agriculture Ecosystems and Environment 225: 116-125.

Catarino L, Romeiras MM, Bancessi Q, et al. 2019. Edible leafy vegetables from West Africa (Guinea-Bissau): Consumption, trade and food potential. Foods 8 (10): 493. DOI: 10.3390/foods8100493.

Chambers R. 1994. The origins and practice of Participatory Rural Appraisal. World Development 22: 953-969.

Chauhan SH, Yadav S, Takahashi T, et al. 2018. Consumption patterns of wild edibles by the Vasavas: a case study from Gujarat, India. Journal of Ethnobiology and Ethnomedicine 14 (1): 57.

Clarke LW, Li L, Jenerette GD, Yu Z. 2014. Drivers of plant biodiversity and ecosystem service production in home gardens across the Beijing Municipality of China. Urban Ecosystems 17 (3): 741-760.

Dansi A, Adjatin A, Adoukonou-Sagbadja H, et al. 2008. Traditional leafy vegetables and their use in the Benin Republic. Genetic Resources Crop Evolution 55 (8): 1239-1256.

Das G, Patra JK, Singdevsachan SK, et al. 2016. Diversity of traditional and fermented foods of the seven sister states of India and their nutritional and nutraceutical potential: a review. Frontiers in Life Science 9: 292-312.

Dias JS. 2012. Nutritional quality and health benefits of vegetables: a review. Food and Nutrition Sciences 3: 1354-1374.

Ebert AW. 2014. Potential of underutilized traditional vegetables and legume crops to contribute to food and nutritional security, income and more sustainable production systems. Sustainability 6 (1): 319 335 . 
Food and Agriculture Organization (FAO). 2019. The state of the world's biodiversity for food and agriculture. In: Belanger J, Pilling D (eds.) FAO Commission on genetic resources for food and agriculture assessments. FAO, Rome, Italy.

FAO [Food and Agriculture Organization]. 2001. FAO's state of food insecurity 2001. FAO, Rome, Italy.

Fayemi PO, Muchenje V. 2014. Farmers' preference for mutton and lamb from natural veld in the Eastern Cape Province of South Africa. J Food Agric Environ 12 (2): 15-19.

Germishuizen G, Meyer NL. 2003. Plants of southern Africa: an annotated checklist. Strelitzia 14, National Botanical Institute, Pretoria, South Africa.

Grubben GJH, Denton OA. 2004. Plant resources of tropical Africa 2: vegetables. Backhuys Publishers, Leiden, The Netherlands.

Hammer $\varnothing$, Harper DAT, Ryan RD. 2001. PAST: palaeontological statistics software package for education and data analysis. Palaeontologia Electronica 4: 1-9. http://palaeoelectronica.org/2001_1/past/issue1_01.htm.

Heinrich M, Leonti M, Nebel S, et al. 2005. Understanding local Mediterranean diets: a multidisciplinary pharmacological and ethnobotanical approach. Pharmacol Res 52: 353-366.

Hosu SY, Cishe EN, Luswazi PN. 2016. Vulnerability to climate change in Eastern Cape Province of South Africa: What does the future hold for smallholder crop farmers?. Agrekon 55: 133-167.

Jari B, Fraser GCG. 2012. Influence of institutional and technical factors on market choices of smallholder farmers in the Kat River Valley. In: Van Schalkwyk HD, Groenewald JA, Fraser GCG, Obi A, Van Tilburg A (Eds.), Unlocking markets to smallholders: Lessons from South Africa. Wageningen Academic Press, Wageningen, The Netherlands.

$\mathrm{Ju}$ Y, Zhuo J, Liu B, et al. 2013. Eating from the wild: diversity of wild edible plants used by Tibetans in Shangri-la region, Yunnan, China. Journal of Ethnobiology and Ethnomedicine 9: 28. https://doi.org/10.1186/1746-4269-9-28

Kahane R, Hodgkin T, Jaenicke H, et al. 2013. Agrobiodiversity for food security, health and income. Agronomy for Sustainable Development 33: 671-693

Keatinge JDH, Yang R-Y, Hughes DAJ, et al. 2011. The importance of vegetables in ensuring both food and nutritional security in attainment of the Millennium Development Goals. Food Security 3: 491-501.

Kumar BM, Nair PKR. 2004. The enigma of tropical homegardens. Agroforestry Systems 61: 135-152.

Leonti M, Nebel S, Rivera D, et al. 2006. Wild gathered food plants in the European Mediterranean: a comparative analysis. Economic Botany 60: $130-142$

Manyevere A, Muchaonyerwa P, Laker MC, et al. 2014. Farmers' perspectives with regard to crop production: An analysis of Nkonkobe Municipality, South Africa. Journal of Agriculture Rural Development in the Tropics and Subtropics 115: 41-53.

Mapekula M, Chimonyo M, Mapiye C, et al. 2009. Milk production and calf rearing practices in the smallholder areas in the Eastern Cape Province of South Africa. Tropical Animal Health and Production 41: 1475. https://doi.org/10.1007/s11250-009-9336-5.

Maundu P, Achigan-Dako E, Morimoto Y. 2009. Biodiversity of African vegetables. In: Shackleton CM, Pasquini MW, Drescher AW (Eds.), African indigenous vegetables in urban agriculture. Earthscan, London, UK

Menendez-Baceta G, Aceituno-Mata L, Tardío J, et al. 2012. Wild edible plants traditionally gathered in Gorbeialdea (Biscay, Basque country). Genetic Resources and Crop Evolution 59(7): 1329-1347.

Misra S, Maikhuri RK, Kala CP, et al. 2008. Wild leafy vegetables: a study of their subsistence dietetic support to the inhabitants of Nanda Devi Biosphere Reserve, India. Journal of Ethnobiology and Ethnomedicine 4: 15. https://doi.org/10.1186/1746-4269-4-15.

Mthi S, Skenjana A, Fayemi PO. 2017. Characteristics of smallscale sheep production systems in some communal areas of the Eastern Cape Province, South Africa. International Journal of Livestock Production 8: 199-206.

Mucina L, Rutherford MC. 2006. The vegetation of South Africa, Lesotho and Swaziland. South African National Biodiversity Institute Pretoria, South Africa.

Ndhleve S, Nakin MDV, Longo-Mbenza B. 2017. Impacts of supplemental irrigation as a climate change adaptation strategy for maize production: a case of the Eastern Cape Province of South Africa. Water SA 43 (2): 222-228
Ndhleve S, Musemwa L, Zhou L. 2013. How severe hunger is amongst rural households of the Eastern Cape Province of South Africa. Journal of Economics and Sustainable Development 4: 220-227.

Ngone AM, Ndam LM, Mih AM. 2016. Survey of wild vegetables in the Lebialem Highlands of southwestern Cameroon. Journal of Plant Sciences 4 (6): 172-184.

Ntuli NR, Zobolo AM, Siebert SJ, et al. 2012. Traditional vegetables of northern KwaZulu-Natal, South Africa: Has indigenous knowledge expanded the menu? African Journal of Agricultural Research 7 (45): 6027-6034.

Ochieng J, Afari-Sefa V, Karanja D, et al. 2017. How promoting consumption of traditional African vegetables affects household nutrition security in Tanzania. Renewable Agriculture and Food Systems 33(2): 1-11.

Ojelel S, Mucunguzi P, Katuura E, et al. 2019. Wild edible plants used by communities in and around selected forest reserves of Teso-Karamoja region, Uganda. J Ethnobiol Ethnomed $15 \quad$ (1): 3. https://doi.org/10.1186/s13002-018-0278-8.

Ojiewo CO, Tenkouano A, Hughes JA, et al. 2015. The role of vegetables and legumes in assuring food, nutrition and income security for vulnerable groups in Sub-Saharan Africa. World Medical and Health Policy 7 (3): 187-210.

Orech FO, Aagaard-Hansen J, Friis H. 2007. Ethnoecology of traditional leafy vegetables of the Luo people of Bondo district, western Kenya. International Journal of Food Sciences and Nutrition 58 (7): 522-530.

Romojaro A, Botella MA, Obon C, et al. 2013. Nutritional and antioxidant properties of wild edible plants and their use as potential ingredients in the modern diet. International Journal of Food Sciences and Nutrition 64 (8): 944-952.

Rubatzky VE, Yamaguchi M. 1997. Importance of vegetables in human nutrition. In: Rubatzky VE, Yamaguchi M (Eds.), World vegetables. Chapman and Hall, New York, USA.

Rush E, Savila F, Jalili-Moghaddam S, et al. 2019. Vegetables: New Zealand children are not eating enough. Frontiers in Nutrition 5: 134. DOI: $10.3389 /$ fnut.2018.00134

Sansanelli S, Ferri M, Salinitro M, et al. 2017. Ethnobotanical survey of wild food plants traditionally collected and consumed in the Middle Agri Valley (Basilicata region, southern Italy). J Ethnobiol Ethnomed 13: 50 .

Schreinemachers P, Simmons EB, Wopereis MCS. 2018. Tapping the economic and nutritional power of vegetables. Global Food Security 16: $36-45$

Semenya SS, Maroyi A. 2020. Assessment of useful alien plant species cultivated and managed in rural home gardens of Limpopo province, South Africa. Scientifica article ID 3561306. https://doi.org/10.1155/2020/3561306

Shin T, Fujikawa K, Moe AZ2018. Traditional knowledge of wild edible plants with special emphasis on medicinal uses in Southern Shan State, Myanmar. J Ethnobiol Ethnomed 14 (1): 48 . https://doi.org/10.1186/s13002-018-0248-1.

Sundriyal M, Sundriyal RC. 2004. Wild edible plants of the Sikkim Himalaya: marketing, value addition and implications for management. Economic Botany 58 (2): 300-315.

Tardío J, Pardo-de-Santayana M. 2008. Cultural importance indices: A comparative analysis based on the useful wild plants of southern Cantabria (Northern Spain). Economic Botany 62: 24-39.

Thakur D, Sharma A, Uniyal SK. 2017. Why they eat, what they eat: patterns of wild edible plant consumption in a tribal area of Western Himalaya. Journal of Ethnobiology and Ethnomedicine 13: 70. DOI: 10.1186/s13002-017-0198-z.

Thorn JPR, Thornton TF, Helfgott A 2020. Indigenous uses of wild and tended plant biodiversity maintain ecosystem services in agricultural landscapes of the Terai Plains of Nepal. Journal of Ethnobiology and Ethnomedicine 16: 33. https://doi.org/10.1186/s13002-020-00382-4.

Towns AM, Shackleton C. 2018. Traditional, indigenous, or leafy? A definition, typology, and way forward for African vegetables. Economic Botany 72 (4): 461-477.

Trotter RT, Logan MH. 1986. Informant census: A new approach for identifying potentially effective medicinal plants. In: Etkin LN (Ed.), Plants in indigenous medicine and diet. Redgrave, New York, USA.

Turner NJ, Luczaj LJ, Migliorini P, et al. 2011. Edible and tented wild plants, traditional ecological knowledge and agroecology. Critical Reviews in Plant Sciences 30: 198-225.

Turreira-García N, Vilkamaa AM, Byg A. 2017. Diversity, knowledge, and use of leafy vegetables in northern Thailand: Maintenance and 
transmission of ethnobotanical knowledge during urbanization. Natural History Bulletin of the Siam Society 62 (1): 85-105.

Ülger TG, Songur AN, Çrak O, et al. 2018. Role of vegetables in human nutrition and disease prevention. In: Asaduzzaman M, Asao T (Eds.), Vegetables: Importance of quality vegetables to human health. IntechOpen Ltd., London, UK
Uprety Y, Poudel RC, Shrestha KK, et al. 2012. Diversity of use and local knowledge of wild edible plant resources in Nepal. Journal of Ethnobiology and Ethnomedicine 8: 16. DOI: 10.1186/1746-4269-816.

Welbaum GE. 2015. Vegetable production and practices. Cabi, Wallingford, UK. 